\title{
An overview of conflicts against coal in Eastern India using critical environmental justice framework
}

\section{Roy Brototi*}

Abstract. Coal in India is considered more than a commodity with diverse social, cultural and political implications. It symbolizes a moral endeavor linked with economic development and nation-building in the popular imaginary. Despite this, extraction and use of coal to produce electricity leads to conflicts, involving marginalized, often indigenous communities. The state of Jharkhand in the eastern part of the country contains the highest coal reserves and has many conflictive mines and thermal power plants. In this article, using the lens of critical environmental justice, I analyze ten cases of coal conflicts in Jharkhand to provide an overview about the people mobilizing, the types of mobilizations and the outcomes. Looking at the four pillars of critical environmental justice scholarship, I analyze in depth one case study to show the need for critical research to study conflicts involving marginalized communities and for expanding the boundaries of the field.

Keywords: critical environmental justice, coal, India, ecological distribution conflicts, political ecology.

* Estudiante de doctorado en el Institut de Ciència i Tecnologia Ambientals, Universitat Autònoma de Barcelona (ICTA-UAB). 


\section{Introduction}

On 24 September 2014, The Supreme Court of India, the apex court of the country, ordered the deallocation of 214 out of the 218 coal blocks allocated between 1993 and 2010. This was based on the judgement delivered on 25 August 2014 which had declared that the allotments of coal blocks made by the government were illegal and arbitrary. This was the culmination of two years of investigation which began after a draft report by the Comptroller and Auditor General of India accusing the Government of India for allocating coal blocks inefficiently was leaked to the public in March 2012. Discussions on corruption and crony capitalism soon entered the picture. Popularly known as the Coalgate scam, this was one of the major political scandal of recent years, causing an uproar about the illegal and corrupt way the coal sector in India works (Sarma, 2013). The verdict in itself had far-reaching economic, political and legal consequences (Ananth, 2012). However, despite this, India was the second largest producer and importer of coal in 2017 (IEA, 2018), and reliance on coal in India is not expected to decline anytime soon (Seetharaman).

This is because coal in India is considered much more than a commodity. It is viewed as the resource backbone of India's post-independence development which led to strengthening the public sector of India (Ghosh, 2016). It has wider social, cultural, and political connotations which links it to economic development, nationalism, and nation-building, allowing coal extraction to symbolize a moral endeavor (Lahiri-Dutt, 2016). However, this coal-led industrial development has led to large scale displacement and destruction of the lives, livelihoods and cultural 
heritages of many subsistence communities in India (Talukdar, 2016). Coal thus remains a contested resource which does not address India's interlinked socio-ecological challenges. This has led to ecological distribution conflicts (EDCS) in different parts and using different means and methods of mobilization across the country.

Ecological distribution conflicts are studies in political ecology as social conflicts born from the unfair access to natural resources and the unjust burdens of pollution (Martínez-Alier, 2002). It can be considered as a term for collective claims against environmental injustices, which describe how the destruction caused to the environment is closely linked to and mirror those of the most marginalized communities. The aim of environmental justice is thus to reorder the preexisting power relations. Hence, critical research on such ecological distribution conflicts and the subsequent environmental justice movements that it gives rise to should analyze intersecting forms of inequalities, on different levels using multi-scalar approaches, incorporating the question of expendable people and places (Pellow, 2017).

Research on the expendability of human and non-human population facing socio-ecological threats is limited in the environmental justice scholarship; although the concept of «sacrifice zone» has been used to discuss specific communities which face conflicts due to extractive activities, a critical environmental perspective argues that entire populations are considered expendable, and not just localized spaces (Pellow, 2017). In the context of India, this population has historically been the indigenous communities, who are known as adivasis (translated as the original inhabitants). Many large-scale projects involving coal have led to loss of land, livelihood and tradition and heritage of the adivasis, resulting in such projects in the name of «development» being termed as «displacement projects» (Padel and Das, 2010). 
In this article, I will focus on ten cases of coal conflicts involving adivasis in the state with the highest coal reserves in the country- Jharkhand. By doing a qualitative comparative analysis of ten cases from the EJAtlas I will first highlight some of the key features of the conflicts around coal mining and thermal power plants, including the key actors mobilizing, the forms of protests, and the outcomes. This would then be complemented with an in-depth case study of a particular conflict involving setting up of a thermal power plant in one of the tribal districts of the state. This case study reflects the multiple ways in which people who struggle to protect their land, livelihood and culture are subjected to violence. I conclude that the reason why these different ways of oppression and subjugation continues to benefit private entities against entire population and the environment, is because the indigenous community is considered expendable.

The paper is structured as follows. The next section presents the theoretical framework and the methodology used for the paper. This is followed by a short background of the history of coal in India and the history of the state of Jharkhand to contextualize the findings. In following section on results first provides a brief overview of ten conflicts against coal in Jharkhand, looking at both thermal power plants and coal mining, providing general overview on methods of mobilization, stakeholders involved and the impacts and outcome. It then focuses on a specific case study from one of the tribal districts, providing an in-depth analysis of the struggles and protests of indigenous people against two consequent cases of thermal power plants in the same place and the multiple conflicts it generates. It highlights the systematic denial of rights and recognition of the marginalized communities. In the last section, I conclude that this 
is not an isolated case and is not endemic to either the commodity coal, or the region, Jharkhand. In fact, violation and non-recognition of tribal rights and environmental justice struggles, often mired with violence, is prevalent, not only across scheduled areas of India, both in central and north east, and across commodities, but across the globe (Barbora, 2017). This is because these communities are considered expendable due to historic oppression. Hence, this paper shows the need to broaden the understanding of ecological distribution conflicts and its linkages with larger social injustices involving indigenous vulnerable communities using a critical environmental justice framework.

\section{Theoretical Framework}

\section{Political Ecology as the Study of Ecological Distribution Conflicts}

Political ecology (PE) is the study of the relationships between political, economic and social factors with environmental issues and changes (Robbins, 2004). In other words, PE is at the confluence between ecologically rooted social science and the principles of political economy. PE understands every ecological issue as a political one. Politics has to do with the distribution of power and resources within a given group, community and society; within and across generations. The academic community of PE offers a wide range of studies integrating ecological social sciences with political economy (Peet and Watts, 2004) in topics such as degradation and marginalization, environmental conflict, conservation and control, environmental identities and social movements (Robbins, 2004). Scholars 
in PE are drawn from a variety of academic disciplines, including geography, anthropology, development studies, political science, sociology, forestry, and environmental history.

PE's broad scope and interdisciplinary nature lends itself to multiple definitions and understandings. However, common assumptions across the field give it relevance (Bryant and Bailey, 1997). have developed three fundamental assumptions in practicing PE:

1. Costs and benefits associated with environmental change are distributed unequally. Changes in the environment do not affect society in a homogenous way: political, social, and economic differences account for uneven distribution of costs and benefits.

2. This unequal distribution inevitably reinforces or reduces existing social and economic inequalities. In this assumption, political ecology runs into inherent political economies as «any change in environmental conditions must affect the political and economic status quo.»

3. The unequal distribution of costs and benefits and the reinforcing or reducing of pre-existing inequalities holds political implications in terms of the altered power relationships that now result.

This understanding resonates with the definition given by (Martinez-Alier, 2002): PE is the study of ecological distribution conflicts, meaning the study of conflicts on the access to natural resources and services and on the burdens of pollution or other environmental impacts that arise from social asymmetries in the distribution of political and economic power, property rights and income. In addition, PE attempts to provide critiques as well as alternatives in the interplay of the environment and political, economic and social factors, with an aim to eventually engage with social mobilization against such conflicts for justice. 
Justice requires not just an understanding of unjust distribution and a lack of recognition, participation, and capabilities but, importantly, the way in which these are tied together in social, cultural, and political processes (Scholsberg, 2009). Hence sociologist Stella Capek provided six key claims for understanding environmental justice -access to correct and adequate information about environmental hazards, public hearings, democratic participation in the decision making process by the affected people, compensation to the people suffering from the people benefiting from such projects, solidarity with the survivors of such conflicts, and finally a call to eradicate environmental injustices everywhere (Capek, 1993).

In recent past, a critical environmental justice scholarship has been proposed by David Pellow (2016) with four main pillars. The first pillar consists of recognizing the different ways in which multiple forms of inequality and oppression intersect-in both the human and the non-human world. The second pillar focuses on the multiple scales at which environmental injustices manifest. It calls for diverse methodological and theoretical approaches to develop a broader understanding of complex temporal and spatial reasons and finding more grounded resolutions of environmental justice struggles. The third pillar considers the present social order as a hindrance to socio-environmental justice due to the historical and embedded social inequality it represents. It proposes to deepen direct democratic processes without depending on state institutions. Finally, the fourth pillar introduces the concept of indispensability as all communities and species are connected and dependent on each other. It challenges ideologies of dominance and suppression of excluded and marginalized people and places.

Not surprisingly, critical environmental justice scholarship draws from different fields including political ecology (Pellow, 2017). 
In this article, using the framework of critical environmental justice scholarship, I will first provide an overview of coal conflicts in the state of Jharkhand in eastern India and then delve into a case study to examine the relevance of these four pillars. These conflicts over coal are part of a broader environmental justice movement in India, claiming autonomy and socio-ecological well-being in the face of the political-metabolic (re)configuration of the country (Roy and Martínez-Alier, 2019). Land dispossession, on which the expansion of coal mining often relies, is a heavily protested mechanism at other extractive frontiers (D'Costa and Chakraborty, 2017). Many environmental justice movements in India arise from conflicts over land acquisition (Chakraborty, 2013), related to extractive as well as to renewable energy projects (Ávila, 2018) and to wider regimes of dispossession (Oskarsson and Boo, 2017), placing them within the global environmental justice movement (Martínez-Alier, 2016).

\section{Methodology}

I have implemented a mix of direct observation, fieldwork data and secondary literature to analyze conflicts against coal in the eastern Indian state of Jharkhand. I have conducted fieldwork in India, in the state of Jharkhand, as well as in states of Andhra Pradesh, Telangana, Odisha, Goa and West Bengal for six months between 2017 and 2019. The fieldwork consists of 36 in-depth interviews with different stakeholders, representing the communities affected by coal projects, coal company representatives and government officials, as well as activists and journalists who have worked intensively on the tribal rights and environmental justice issues. I have also participated as a 
direct observer in the annual meeting on forest rights in Ranchi, the capital of Jharkhand in 2019, the national gathering of activists fighting against coal mining and thermal power plants in the coal capital of the country Dhanbad and academic workshops on land and tribal rights in New Delhi in 2017. The case study on Godda is largely informed by my fieldwork. I have also carried out an extensive study of secondary literature, covering academic publications and grey literature such as newspaper articles, Right to Information reports, legal documents, company reports, and activists' reports for analyzing the overview of coal conflicts. I further analyzed the data on the ten cases of coal conflicts registered in the Environmental Justice Atlas (www.ejatlas. org), some of which I have filled myself.

The Environmental Justice Atlas (EJAtlas), which was launched in March 2014, is a tool created to document and catalogue such ecological distribution conflicts worldwide. The theoretical framework is rooted in activist knowledge and a bottom-up methodology was implemented to create the data collection form of the EJAtlas of about ten pages (Temper and Del Bene, 2015). Although I have used cases reported in the EJAtlas for the overview of coal conflicts in Jharkhand, I have created my own categories to better analyse the similarities and differences in each of the cases. For example, in all the cases studied, there is involvement of local people in all the cases, and no involvement of recreational users or recyclers, hence I have not included those in the groups mobilizing. For the sake of simplicity, I have used four different mobilizing groups, which are —indigenous communities, environmental justice organizations from outsite the region which could be both national or international organizations, political parties, and women. Similarly, in the EJAtlas form there are 28 forms of mobilization, which I have categorized as direct action and indirect action for this article. Direct 
action would include forms of mobilizations such as strikes, blockades, land occupation etc, whereas indirect action would include judicial and financial activism, media based activism, creation of alternative reports etc. For the category of outcomes, the EJAtlas has list of 26 non-exclusive outcomes. However, for this article, I have created my own variable for conflict outcomes to understand what were the effects of the environmental justice movement on the coal mining or the thermal power plant projects. These variables are Stopped, Modified, Delayed and Continuing (with no changes), and are explained in details in section on the overview of the conflicts.

\section{History of coal in India}

Coal in India has a long history. The first coal mine was started during colonial times in 1774 in Raniganj and the first thermal power plant, known as the Emambagh Power Station was commissioned in 1899 by the Calcutta Electricity Supply near Princep Ghat, both in the current state of West Bengal in eastern India (Lahiri-Durr, 2014; Bhattacharjee, 2017). However, it was after India's independence in 1947 where laws were passed, and organizations set up for shaping the coal economy as we know today. To boost industrial development, need for coal production was stressed in the first five-year plan, with a working party for coal industry being set up in 1951. In 1956, the National Coal Development Corporation (NCDC) was set up, with the collieries owned by the railways as its center. This was the first step towards the development of the Indian Coal Industry. In 1957, the Coal Bearing Areas Acquisition and Development Act was also passed which circumvents the protection legislation for tribals. This was 
followed by the nationalization of coal with the enactment of the Coal Mines (Nationalization) Act, 1973.

\section{The rise in Indian coal extraction}

There has been continued rise in coal extraction in India between 1966 and 2014. Coal reserves are concentrated in the central and eastern part of the country. The states of Madhya Pradesh, Chhattisgarh, Jharkhand, Orissa, and Andhra Pradesh together mine about $85 \%$ of coal in the country (Government of India, 2015).

\section{Figure 1}

Coal extraction in India from 1966-2014

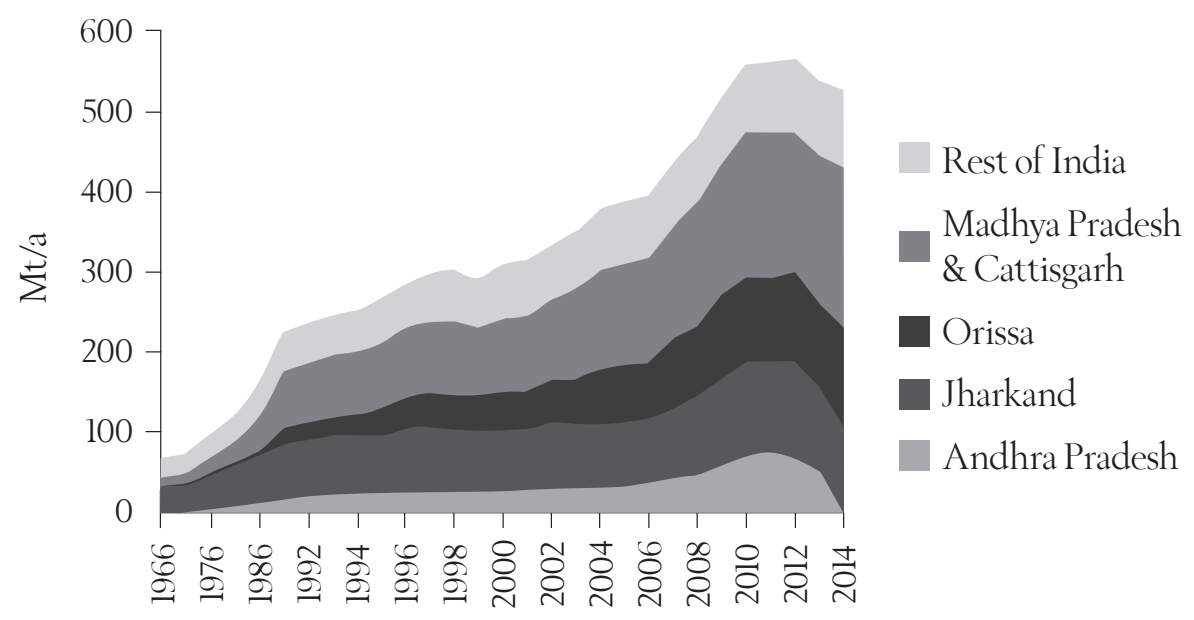

Source: Government of India, 2015. 
ROY BROTOTI

\section{Background of Jharkhand}

The state of Jharkhand was created in 2000 addressing tribal demands (Munda and Bosu, 2003). Jharkhand is one of the most resource rich states of India, with one-third of the country's total coal reserve (Lahiri-Dutt, Krishnan and Ahmad, 2012). There is also literature suggesting this state suffers from resource curse (Nathan and Dayal, 2009).

\section{Figure 2}

Location of Jharkhand in the map of India

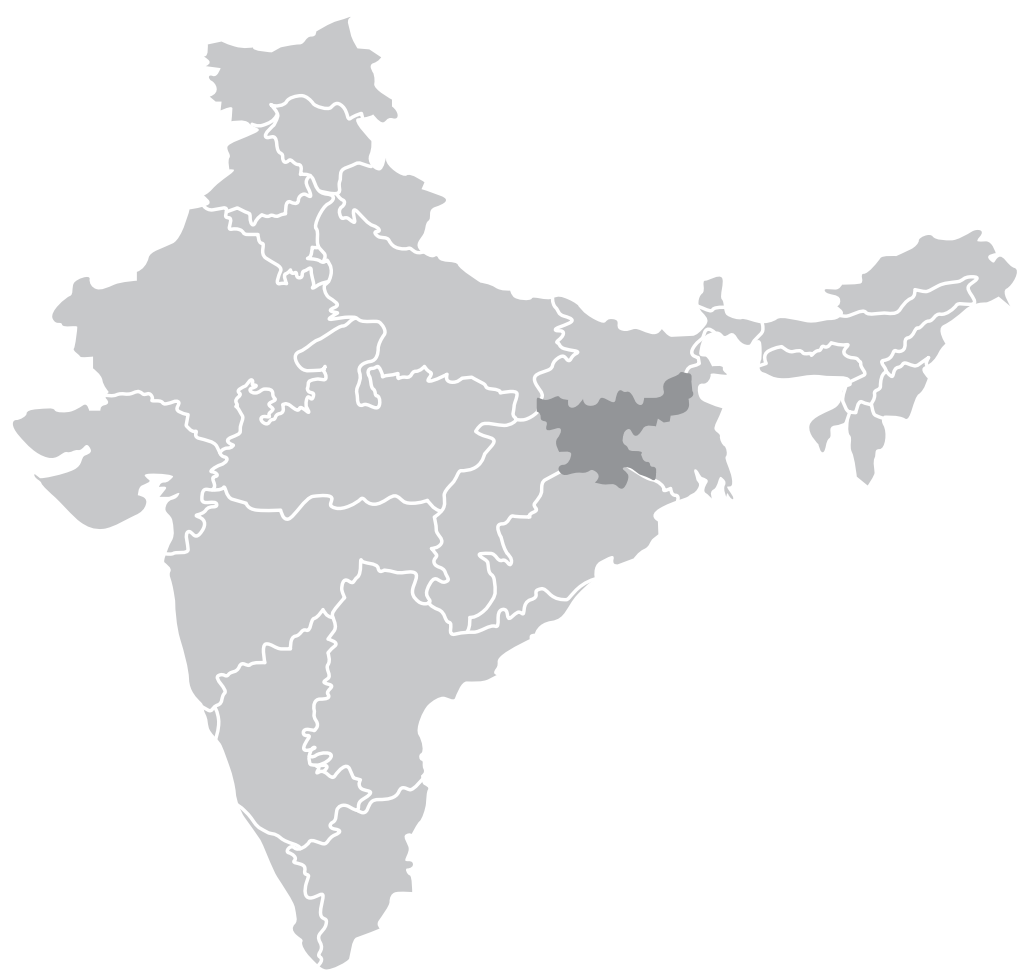


With the country's highest coal reserves, the state is home to about one-third of India's total coal reserve. It consists of 24 districts and is a part of the Chotanagpur plateau. Consequently, a lot of coal mines and thermal power plants are in various stages of operation in areas with high tribal population (Mahato, 2012). One such thermal power plant, currently being constructed and fraught with protests, is located in the district of Godda. It is one of the twenty-four districts of the state of Jharkhand, lying in the northeastern part of the state and with a large tribal presence.

\section{An overview of ecological distribution conflicts over coal in Jharkhand}

In this section, I present an overview of ten cases of EDCs involving coal in the state of Jharkhand.

Table 1

Details of ten coal conflicts in Jharkhand

\begin{tabular}{|c|c|c|c|c|c|c|c|}
\hline & $\begin{array}{l}\text { Name of } \\
\text { Conflict }\end{array}$ & Type & $\begin{array}{l}\text { Start } \\
\text { Year }\end{array}$ & $\begin{array}{c}\text { Mobilization } \\
\text { types }^{*}\end{array}$ & $\begin{array}{c}\text { Groups } \\
\text { Mobilizing }\end{array}$ & Outcomes & $\begin{array}{l}\text { Deaths } \\
\text { (Nos.) }\end{array}$ \\
\hline 1 & $\begin{array}{l}\text { APNRL } \\
\text { plant in } \\
\text { Padampur }\end{array}$ & $\mathrm{P}$ & 2013 & DA & $\mathrm{I}, \mathrm{E}$ & Modified & \\
\hline 2 & $\begin{array}{l}\text { Bhusan } \\
\text { power }\end{array}$ & $\mathrm{P}$ & 2006 & DA and IA & I, E, P & Continuing & \\
\hline 3 & $\begin{array}{l}\text { NTPC } \\
\text { Hazaribagh }\end{array}$ & M & 2004 & DA and IA & I, E, P, W & Delayed & 4 \\
\hline 4 & $\begin{array}{l}\text { Tilaiya } \\
\text { UMPP }\end{array}$ & $\mathrm{P}$ & 2012 & DA and IA & I, E, P, W & Stopped & \\
\hline
\end{tabular}




\begin{tabular}{cccccccc} 
& $\begin{array}{c}\text { Name of } \\
\text { Conflict }\end{array}$ & Type & $\begin{array}{c}\text { Start } \\
\text { Year }\end{array}$ & $\begin{array}{c}\text { Mobilization } \\
\text { types }^{*}\end{array}$ & $\begin{array}{c}\text { Groups } \\
\text { Mobilizing** }\end{array}$ & Outcomes & $\begin{array}{c}\text { Deaths } \\
\text { (Nos.) }\end{array}$ \\
\hline 5 & $\begin{array}{l}\text { Ganeshpur } \\
\text { coal mine }\end{array}$ & M & 2009 & DA & I & Delayed & \\
6 & $\begin{array}{l}\text { Jharia fire } \\
7\end{array}$ & M & 2006 & DA and IA & I, P & Continuing & \\
indal plant & P Godda & 2013 & DA & I, W & Stopped & \\
8 & $\begin{array}{l}\text { Kusum Tola } \\
\text { Pakrih }\end{array}$ & M & 2009 & DA and IA & I, E, W & Delayed & 1 \\
9 & $\begin{array}{l}\text { Barwadih } \\
\text { Banem }\end{array}$ & M & 2010 & DA & I,P & Delayed & \\
10 & $\begin{array}{l}\text { Panem } \\
\text { mines }\end{array}$ & M & 2012 & DA & I, E, P & Modified & 1 \\
\hline
\end{tabular}

*DA: Direct Action / IA: Indirect Action

**Indigenous groups (I), EJOs from outside (E), political parties (P), women (W).

Source: EJAtlas, 2014a; 2014b; 2014c; 2014d; 2014e; 2014f; 2014g; 2016; 2018a; 2018 b.

\section{Types of conflicts}

According to table 1, there are 6 cases of conflicts against mining and 4 against construction of thermal power plants. However, the case of Tilaiya Ultra Mega thermal project is a conflict which involves both a thermal power plant and a coal mine, since there have been protests at the sites of the construction of the plant and the extraction of coal from the mines (EJAtlas, 2014g).

\section{Starting dates of conflicts}

The oldest conflict started in 2004 and the most recent one in 2013. However, in the case of Jharia, mining had first started in 1896, yet the current 
conflict began in 2006 after the massive rehabilitation plan called the Jharia Action Plan failed to deliver on its promise of proper rehabilitation and compensation. Sometimes conflicts gain media attention many years later, due to large demonstrations or use of violence against the protestors. As an example, the oldest case which started in 2004 in Hazaribagh came into limelight in 2016 when police openfired on protestors in the wee hours of 1 October, killing 5 people and injuring several more (Chowdhury, 2016).

\section{Types of Mobilization}

In all the cases reported, there were direct mobilizations, often in the form of demonstrations, blockades, strikes etc. In five of them, it was also complemented by indirect activism such as judicial or media based activism. In many cases the judicial or media based indirect activism is carried out by activists and NGOs from outside the region, such as in the case of Tilaiya, where Centre for Science and Environment send complaint letters and petitions to the government in protest against an inaccesible public hearing venue (Ramanathan, 2015) and in the case of Bhusan Power and Limited Project, where ToxicsWatchAlliance sent letter to the Ministry of Environment and Forest against an illegal public hearing (Krishna, 2012).

\section{Groups Mobilizing}

In all the cases, indigenous communities were involved. This is not surprising since Jharkhand has a significant proportion of tribal presence. The state was 
created in 2000 after decades of protests for autonomy by the tribal communities of the region (Munda and Bossu, 2003). Environmental justice organizations from inside and outside the region, both national and international are active in these movements. The prominent ones among them are Centre for Science and Environment, Akhil Bharatiya Adivasi Mahasabha (All India Tribal General Assembly), Karanpura Sangharsh Samiti (Save Karanpura Committee) and Bindrai Institute for Research, Study and Action.

\section{Outcomes}

Despite the wide range of protests and the different groups mobilizing, these movements are unable to prevent the projects from stopping. The two cases in which projects were stopped are in Tilaiya and Godda. In the case of Tiliaya, the project was stopped when Reliance power pulled out of the project, but the state government has plans to re-award the project again once the new bidding rules for such mega projects are finalized (Jai, 2018). In the case of Godda, although the project by Jindal was scrapped, a new project involving the same community and in the same region was started by Adani amidst protests, as described in the case study below. However, in most of the cases the protests are successful in delaying the projects, negotiating for better compensation, jobs for the communities displaced, better pollution measures etcetera (Jenamani, 2014; Sen, 2013).

\section{Violence and Deaths}

In each of the ten reported cases, protested have faced direct violence in one form of the other-be it baton charges by the police during demonstrations 
and strikes, arrests and false court cases, and multiple injuries. There were at least 4 reported deaths on October 1, 2016 when police open-fired on protesting villagers against the NTPC power plant in Hazaribagh (Chowdhury, 2016). In 2011, Sister Valsa John, who was very vocal against coal mining mafias in Panem was murdered (Chandrasekhar, 2019) and in 2018, Suresh Oraon faced the same fate due to his fight against displacement and pollution due to coal mining in the region (Kiro, 2018). There have also been «suspicious» deaths of multiple other activists who have been working against coal projects involving the coal mafia in the region (The Research Collective, 2015).

\section{A thermal power plant with imported coal for exporting electricity in a coal-rich, electricity-poor district}

The district of Godda lies in the northeastern part of the state. It has an area of $2110 \mathrm{~km}^{2}$ and a population of 1.31 million, according to the Census of India 2011. It consists of nine blocks and 2311 villages, and the only one town Godda, which is the headquarter of the district. It used to be a part of the older Santhal Parganas district and has a large tribal presence.

The Adani thermal power project is not the first such project in this region. In 2013, the foundation stone for a 1,320 MW thermal power plant by Jindal Steel and Power Limited was laid by the then President Pranab Mukherjee, which had an estimated cost of Rs. 8,500 crores and an expectation of providing employment (direct and indirect) to 20,000 people (Yadav, 2013a). This project was lauded as Jharkhand's first power plant based on Super Critical Technology with two units of 660 MW each. 
It was supposed to use coal from the nearby Jitpur coal block and water from Sundar dam, Gumani and Jalhara rivers to operate and provide electricity to the rural areas which faced a shortage of 33 per cent (Yadav, 2013b). However, the project faced a lot of protests from the local population (EJAtlas, 2014d). People from 11 villagers which were to be directly affected by this project had been opposing the land acquisition of this project. Even on the day of the foundation stone ceremony, about 200 villagers had decided to march to the place of the ceremony, however more than 50 adivasi farmers, including women were detained for more than six hours to prevent them from marching to the site (Yadav, 2013a).

However, in 2014, the Jitpur coal block was deallocated in the wake of the Supreme Court's decision deeming most coal blocks allocated between 1993 and 2010 as illegal and arbitrary. However, in subsequent auctions held in March 2015, Jitpur was won by the Adani group, which was the basis for Adani to propose its power plant project in Godda.

\section{The Adani power plant}

In August 2015, a Memorandum of Understanding was signed with the Bangladesh Power Development Board to supply all the power from Godda power plant to Bangladesh. This was in light of the joint declaration on bilateral cooperation between India and Bangladesh which was signed in June 2015 when Prime Minister Narendra Modi visited Bangladesh. Consequently, in 2016 the government of Jharkhand signed an MoU to this end with Adani. In the initial proposal the coal needed for electricity generation was to be supplied from the Jitpur mines, which are about 20kms away. 
However, in 2016, the company revised the proposal and stated that it would be using imported coal instead, which would be brought in via the Dhamra port in Odisha. This port is at a distance of 700kms away and owned by the port subsidiary of Adani. And the coal from the Jitpur mines would also be sent further away, over 2000kms to the Mundra power plant in Gujarat.

The rise of the conflict began when ten villages became contested territory due to the construction of the power plant which required over 2000 acres of land. Between 2016 and 2019 (and still ongoing) there have been multiple cases of illegalities including threats and physical violence on the tribal people who have raised their voices against this project. From destroying crops to preventing entry into the public hearings, from false charges on local activists and journalists to contested claims of compensations being paid, there is a dominant narrative in the town that this isn't really a conflict, and it is only after we met the tribal villagers being affected that we could see the contradictory statements being made. However, there are two court cases- one in the Ranchi high court about disputes around the land acquisition, and another with the National Green Tribunal about the water availability of the project.

In March 2019, the company had received formal approval of 222.68 hectares and in-principal approval of 202.32 hectares for the project. There have also been systematic amendments in the state's energy policy, which allowed Adani to charge higher price than other thermal projects in the state. In February 2019, this project became India's first standalone power project to get the status of a Special Economic Zone, with its tax benefits (Chandrasekhar, 2019).

The case of the thermal power plant in Godda gives rise to at least three different EDCs — one at the site of the construction of the plant, 
one at the site of the source of water and one at the site of source of the construction material (sand from the riverbeds). There are latent conflicts brewing at the site of the water source which would affect a lot of communities dependent on the rivers from where the power plant has proposed to source its water, as well as the land under which the pipelines would be constructed. This is also coupled with the rampant illegal sand mining which the locals point out to, and which cannot be easily quantified as it is carried out during the night, and under the influence of a sand mafia. However, if we trace it out further, we can also connect it with the ongoing EDC in the Charmichael coal mines in Australia where a large population is protesting against Adani's mine which poses threat to the Great Barrier Reef (as well as other coal mining sites in Indonesia) to the simmering conflicts in the port areas in coastal India and throughout the transportation channels, including the high tension transmission lines for exporting the electricity to Bangladesh. There are also reports which argue that the power purchase agreement puts Bangladesh at great financial risk and will «deepen» poverty in the country.

\section{Discussion}

However, the argument continuously provided by the state authorities is that this project, as well as the old one would usher in growth and development. This is despite clear evidence of the harm it will cause the adivasi communities as well as the environment due to which there have been ongoing protests since the first plant. Yet, the thermal power plant is being constructed and expected to be commissioned by 2021. This raises 
the question about the parameters which we use to understand development, and who really benefits and who suffers from it.

\section{The cost of development}

Analyzing it from the pillars of critical environmental justice scholarship, the case of Godda can only be understood in its full complexity once we understand the imbedded social and structural hierarchies in the society. The villagers protesting are adivasis, whereas the upper caste communities who have ancestral homes on the land but live outside the district were willing to sell the land for the thermal plant construction. This is because they neither grow the crops in the fertile land which would be turned into a power plant, nor would the ensuing pollution harm them. This inequality and othering of the adivasis also seeps into the state authorities and district administration who belittle the demands of the indigenous communities and proclaim that they are anti-development and are preventing the growth of the state. In this sense, they pay the cost of development and are thus dispensable. And this conflict in itself, once looked from multiple scales, spaces and times shows the far-reaching impacts- starting from the multiple conflicts it generated over time (first Jindal, then Adani), over space (giving rise to three other types of conflicts all related to the thermal power plant) and in far off places like Bangladesh and Australia, all liked to the commodity chain of this coal conflict. 


\section{Conclusions}

Conflicts over natural resources are rampant around the world. It often involves indigenous people as well as violent and dangerous clashes. Conflicts over coal follow a similar pattern and poses additional threat due to the impact of carbon dioxide emissions on climate change.

These patterns include invoking the need for development — in a very narrow sense of what constitutes desirable development — as justification for forced displacement and ecological destruction. This demonstrates the need for a critical environmental justice scholarship to understand the socio-ecological and political complexities involved in such ecological distribution conflicts, so as to move towards environmental justice.

In this article I only look at direct, physical violence, due to its high intensity in each of the cases for the overview as well as to understand how adivasis are seen as dispensable in the case study. However, violence manifests in different forms and must also be understood using a multidimensional framework when studying ecological distribution conflicts which includes slow and structural forms of violence (Navas, Mingorria and Aguilar-González, 2018). This would go hand in hand with understand the multiple oppression and marginalization which intersect each other, using a critical environmental justice framework. This is true not only for coal in India, but for similar conflicts in other parts of the world involving marginalized communities and species. Hence, this article shows how complex each ecological distribution conflict is and why we need to be more critical to ensure social mobilization towards environmental justice. 


\section{References}

Ananth, V.K. (2012). «Coalgate: a skewed debate». Economic and Political Weekly, 47(40), pp. 22-25.

Avila, S. (2018). «Environmental justice and the expanding geography of wind power conflicts». Sustainability Science, 13(3). pp. 599-616. DOI: https://doi. org/10.1007/s11625-018-0547-4

Barbora, S. (2017). «Riding the rhino: conservation, conflicts, and militarisation of Kaziranga National Park in Assam». Antipode, 49(5), pp. 1145-1163. DOI: https://doi.org/10.1111/anti.12329

Bhattacharjee, S. (2017). India's coal story: from Damodar to Zambezi. New Delhi: SAGE Publishing.

Bryant, R. and Bailey, S. (1997). Third world political ecology. London: Routledge. Capek, S.M. (1993). «The renvironmental justices frame: a conceptual discussion and an application». Social Problems, 40(1), pp. 5-24.

Chakravartty, A. (4 July 2015). «People's tribunal throws new light on sister Valsa John's Murder». Down to Earth. Retrieved from https://www.downtoearth. org.in/news/peoples-tribunal-throws-new-light-on-sister-valsa-johns -murder--47480

Chakravorty, S. (2013). The price of land: acquisition, conflict and consequences. New Delhi: Oxford University Press.

Chandrasekhar, A. (25 March 2019). «In final days of Modi government, Adani project in Jharkhand becomes India's first power sector SEZ». Scroll.

Chowdhury, M. (5 October 2016). «Shoot us all: Hazaribagh still in shock at police firing on protest against land acquisition». Scroll.

D'Costa, A. and Chakraborty, A. (2017). The land question in India: State, sispossession and capitalist transition. Oxford University Press. 
EJAtlas (2014a). «APNRL coal power plant in Padampur, Jharkhand, India». Atlas of Environmental Justice. Retrieved from https://www.ejatlas.org/conflict/ apnrl-coal-power-plant-in-padampur-jharkhand-india

EJAtlas (2014b). «Bhushan power and steel limited, Jharkhand, India». Atlas of Environmental Justice. Retrieved from https://ejatlas.org/conflict/bhushan -power-and-steel-limited-jharkhand-india

EJAtlas (2014c). «Ganeshpur coal mine, Jharkhand, India». Atlas of Environmental Justice. Retrieved from https://ejatlas.org/conflict/ganeshpur-coal -mine-jharkhand-india

EJAtlas (2014d). «Jharia coalfield fire, India». Atlas of Environmental Justice. Retrieved from https://ejatlas.org/conflict/jharia-coalfield-fire-india

EJAtlas (2014e). «Jindal steel captive power plant in Godda, Jharkhand, India». Atlas of Environmental Justice. Retrieved from https:/ejatlas.org/conflict/ jindal-steel-captive-power-plant-in-godda-jharkhand-india

EJAtlas (2014f). «Pakri-Barwadih coal mining in Jharkhand, India». Atlas of Environmental Justice. Retrieved from https://ejatlas.org/conflict/pakri-bar wadih-coal-mining-in-jharkhand-india

EJAtlas (2014g). «Tilaiya ultra mega power project, India». Atlas of Environmental Justice. Retrieved from https://ejatlas.org/conflict/tilaiya-ultra-mega -power-project-india

EJAtlas (2016). «Coal mining conflict in Hazaribagh with NTPC in Jharkhand, India». Atlas of Environmental Justice. Retrieved from https://ejatlas.org/ conflict/illegal-land-acquisition-for-coal-mining-and-violent-protest-inhazaribagh-jharkhand

EJAtlas (2018a). «Kusum Tola, India». Atlas of Environmental Justice. Retrieved from https://ejatlas.org/conflict/kusum-tola-india 
EJAtlas (2018b). «Panem coal mines, Jharkhand, India». Atlas of Environmental Justice. Retrieved from https://ejatlas.org/conflict/panem-coal-mines-india Ghosh, D. (2016). «We don't want to eat coal»: development and its discontents in a Chhattisgarh District in India». Energy Policy, 99, pp. 252-260. DOI: https://doi.org/10.1016/j.enpol.2016.05.046

Government of India (2015). Statistics of Mines in India. India: Government of India.

Grajales, J. (2011). «The rifle and the title: paramilitary violence, land grab and land control in Colombia». Journal of Peasant Studies, 38(4), pp. 771-1192. DOI: https://doi.org/10.1080/03066150.2011.607701

IEA (2018). «World energy statistics». DOI: http://dx.doi.org/10.1787/data-00510-en Jai, S. (19 May 2018). «Jharkhand Govt set to re-award Tilaiya ultra mega power project». Business Standard.

Jenamani, K. (7 February 2014). Pollution rap prompts power firm to plug fly ash pond». The Telegraph.

Kiro, S. (8 June 2018). «Anti-mining activist murdered in Ranchi». The Wire.

Krishna, G. (2012). «Illegal public hearing on Bhushan power \& Steel Ltd Project at Jharkhand's Potka, East Singbhum stopped by villagers». ToxicsWatch. Journal of Earth, Science, Economy and Justice. Retrieved from http:// www.toxicswatch.org/2012/09/illegal-public-hearing-on-bhushan-power. html?m=0

Lahiri-Dutt, K. (2014). The Coal Nation: histories, politics and ecologies of coal in India. Aldershot: Ashgate.

Lahiri-Dutt, K. (2016). «The diverse worlds of coal in India: energising the nation, energising livelihoods». Energy Policy, 99, pp. 203-213. DOI: https://doi. org/10.1016/j.enpol.2016.05.045 
Lahiri-Dutt, K., Krishnan, R. and Ahmad, N. (2012). «Land acquisition and dispossession». Economic and Political Weekly, 47(6), pp. 39-45.

Lakhanpal, S. (2019). «Contesting renewable energy in the Global South: a case-study of local opposition to a wind power project in the Western Ghats of India». Environmental Development, 30, pp. 51-60. DOI: https://doi. org/10.1016/j.envdev.2019.02.002

Mahato, N. (2012). «Land acquisition by coal companies in Jharkhand». Economic and Political Weekly, XLVII(11), pp. 4-5.

Martinez-Alier, J. (2002). The environmentalism of the poor: a study of ecological conflicts and valuation. Edward Elgar. DOI: https://doi.org/10.5860/ choice.40-4110

Martinez-Alier, J., Temper, L., Del Bene, D. and Scheidel, A. (2016). «Is there a global environmental justice movement?». Journal of Peasant Studies, 43(3), pp. 731-755. DOI: https://doi.org/10.1080/03066150.2016.1141198

Mingorría, S. (2018). «Violence and visibility in oil palm and sugarcane conflicts: the case of Polochic Valley, Guatemala». Journal of Peasant Studies, 45(7), pp. 1314-1340. DOI: https://doi.org/10.1080/03066150.2017.1293046

Munda, R.D. and Bosu Mullick, S. (2003). The Jharkhand movement: indigenous people's struggle for autonomy in India. Copenhagen: International Work Group for Indigenous Affairs.

Nathan, D. and Dayal, H. (2009). «Resource Curse and Jharkhand', Economic \& Political Weekly, 44(51), pp. 16-17.

Navas, G., Mingorria, S. and Aguilar-González, B. (2018). «Violence in environmental conflicts: the need for a multidimensional approach». Sustainability Science, 13(3), pp. 649-660. DOI: https://doi.org/10.1007/s11625-018-0551-8>

Oskarsson, P. and Boo Nielsen, K. (2017). Industrialising rural India: land, policy, resistance. London: Routledge. 
Padel, F. and Das, S. (2010). «Cultural genocide and the rhetoric of sustainable mining in East India». Contemporary South Asia, 18(3), pp. 333-341. DOI: https://doi.org/10.1080/09584935.2010.503871

Peet, R. and Watts, M. (2004). Liberation ecologies: environment, development, social movements. London: Routledge.

Pellow, D.N. (2016). «Toward a critical environmental justice studies». Du Bois Review: Social Science Research on Race, 13(2), pp. 221-236. DOI: https://doi. org/10.1017/s1742058x1600014x

Pellow, D.N. (2017). What Is Critical Environmental Justice? Cambridge: Polity Press. Ramanathan, S. (4 July 2015). «Hazaribagh villages up against reliance power». Down to Earth. Retrieved from http://www.downtoearth.org.in/news/ hazaribagh-villages-up-against-reliance-power-38472

Randeria, S. (2004). «Glocalization of law: environmental justice, World Bank, NGOs and the cunning State in India». Global Forces and Local Life-Worlds: Social Transformations, pp. 105-126. DOI: https://doi. org/10.4135/9781446211328.n7

Robbins, P. (2004). Political ecology: a critical introduction, critical introductions to Geography. Malden: Blackwell.

Roy, B. and Martinez-Alier, J. (2019). «Environmental justice movements in India : an analysis of the multiple manifestations of violence». Ecology, Economy and Society- the INSEE Journal, 2(1), pp. 77-92.

Sarma, E.A.S. (2013). «Myopia on coal». Economic and Political Weekly, 48(44), pp. 12-14.

Scholsberg, D. (2009). Defining environmental justice: theories, movements, and nature. Oxford: Oxford University Press.

Seetharaman, G. (12 May 2019). «Coal here to stay despite India's ambitious goals for renewable energy». Economic Times. Retrieved from https://economictimes. 


\section{ROY BROTOTI}

indiatimes.com/industry/energy/power/india-will-not-be-able-to-achieveits-renewable-energy-targets-anytime-soon/articleshow/69286279.cms?from $=\mathrm{mdr} \% 0 \mathrm{~A}$

Sen, A. (7 June 2013). «Protesters halt NTPC mining in Hazaribag». Times of India. Talukdar, R. (2016). «Hiding neoliberal coal behind the Indian poor». Journal of Australian Political Economy, 78, pp. 132-158.

Temper, L., Del Bene, D. and Martinez-Alier, J. (2015). «Mapping the frontiers and front lines of global environmental justice: the EJAtlas». Journal of Political Ecology, 22(1). DOI: https://doi.org/10.2458/v22i1.21108

The Research Collective (2015). Coallateral. New Delhi.

Yadav, A. (1 May 2013). "Police detain Adivasi protesters as president lays foundation for Jindal power plant». The Hindu. Retrieved from https:// www.thehindu.com/news/national/other-states/police-detain-adivasiprotesters-as-president-lays-foundation-for-jindal-power-plant/ article4671126.ece

Yadav, A. (30 April 2013). «Stone laid for Jindal steel's power plant in Jharkhand». The Hindu. Retrievedfrom https://www.thehindu.com/business/Industry/ stone-laid-for-jindal-steels-power-plant-in-jharkhand/article4670652.ece 